\title{
Mediação do erro na educação: um arcabouço de sistema para a instrumentalização de professores e alunos
}

\author{
Aluno: Alexander Robert Kutzke ${ }^{1}$, Orientador: Alexandre Direne ${ }^{1}$ \\ ${ }^{1}$ Programa de Pós-Graduação em Informática - Departamento de Informática \\ Universidade Federal do Paraná (UFPR) \\ Caixa Postal 19.081 - 81.531-980 - Curitiba - PR - Brasil \\ $\{$ alexander, alexd $\}$ @inf.ufpr.br
}

\section{Resumo}

O problema central da mediação do erro na educação escolar e possíveis contribuições da Informática Educativa são expostos de maneira crítica. Embora inúmeras pesquisas e abordagens pedagógicas salientem o importante papel do erro na educação, pouco, ainda, se faz a partir deste na prática. Em um ambiente como o da educação pública no Brasil, onde professores são sobrecarregados, ainda que os registros dos erros não sejam perdidos ou deixados de lado, o volume e o caráter esparso e caótico dos registros mantidos impossibilitam a análise por parte do professor. Nesse sentido, a partir das bases da Psicologia Histórico-Cultural e da Pedagogia Histórico-Crítica, conclui-se que, sem a mediação do erro, professores não possuem condições ideais para refletir sobre seu próprio método de ensino, e os alunos, por sua vez, ficam sem acesso aos seus erros e da mediação dos mesmos pelo professor. De acordo com tal problema, faz-se necessário facilitar o acesso aos registros de erros tanto para professores quanto para alunos, tendo como objetivo final a superação da visão tradicional do erro (aquela que culpabiliza o aluno) e a promoção de sua mediação. Uma mediação que se caracteriza não pela remoção do erro, mas por entendê-lo como parte integrante do processo de formação de conceitos. Por meio da revisão bibliográfica apresentada aponta-se que os atuais sistemas educacionais na informática não proporcionam uma análise aprofundada das conexões existentes entre os erros apresentados por alunos. Neste sentido, este trabalho propõe um arcabouço de sistema para a facilitação da mediação do erro no contexto escolar. Este arcabouço permite ao professor visualizar e manipular registros de respostas e suas relações. Para tanto, desenvolve-se o conceito de grafo de similaridade entre respostas, sobre o qual, com participação ativa do professor, o sistema provê funcionalidades como: classificação semi-automática de respostas, recomendação de respostas para grupo de alunos e diferentes tipos de visualização dos dados armazenados. Com este instrumento, permite-se ao professor uma análise do processo de formação de conceitos do aluno de uma maneira mais concreta e sintética em detrimento de uma visão imediatista e empírica. Uma implementação deste arcabouço para o ensino de programação de computadores é descrita. Relatam-se resultados de experimentos iniciais realizados através do uso da ferramenta em ambientes reais de ensino. De acordo com tais resultados, apontam-se indícios de que a ferramenta e, por consequência, o arcabouço proposto, podem agir positivamente para a mediação do erro no trabalho educativo e na superação da visão tradicional do erro. As principais contribuições da pesquisa são apresentadas e apontam-se trabalhos futuros.

Referência (trabalho completo): KUTZKE, Alexander Robert, e DIRENE, Alexandre. "Mediação do erro na educação: um arcabouço de sistema para a instrumentalização de professores e alunos." Anais do Simpósio Brasileiro de Informática na Educação. Vol. 25. No. 1. 2014. 